\title{
Halorubrum ezzemoulense sp. nov., a halophilic archaeon isolated from Ezzemoul sabkha, Algeria
}

\author{
Karima Kharroub, ${ }^{1,2}$ Teresa Quesada, ${ }^{1}$ Raquel Ferrer, ${ }^{1}$ \\ Susana Fuentes, ${ }^{1}$ Margarita Aguilera, ${ }^{1}$ Abdrahmane Boulahrouf, ${ }^{3}$ \\ Alberto Ramos-Cormenzana ${ }^{1}$ and Mercedes Monteoliva-Sánchez ${ }^{1}$ \\ ${ }^{1}$ Departamento de Microbiologia, Facultad de Farmacia, Campus Universitario de Cartuja s/n \\ 18071, Granada, Spain \\ ${ }^{2,3}$ Institut de Nutrition de l'Alimentation et des Technologies Agro-Alimentaires ${ }^{2}$ and Institut \\ des Sciences de la Nature, Faculté des Sciences ${ }^{3}$, Université Mentouri, Constantine, Algeria
}

Correspondence Mercedes Monteoliva-Sánchez mmonteol@ugr.es
A novel extremely halophilic archaeon was isolated from Ezzemoul sabkha, Algeria. The strain, designated $5.1^{\top}$, was neutrophilic, motile and Gram-negative. At least $15 \%(\mathrm{w} / \mathrm{v}) \mathrm{NaCl}$ was required for growth. The isolate grew at $\mathrm{pH} 6 \cdot 5-9 \cdot 0$, with optimum growth at $\mathrm{pH} 7 \cdot 0-7 \cdot 5 . \mathrm{Mg}^{2+}$ was required for growth. Polar lipids were $\mathrm{C}_{20} \mathrm{C}_{20}$ derivatives of phosphatidylglycerol and phosphatidylglycerol phosphate methyl ester, and phosphatidylglycerol sulfate and sulfated diglycosyl diether. The genomic DNA G $+\mathrm{C}$ content of strain $5.1^{\top}$ was $61.9 \mathrm{~mol} \%\left(T_{\mathrm{m}}\right)$. Phylogenetic analysis based on comparison of $16 \mathrm{~S}$ rRNA gene sequences revealed that strain $5.1^{\top}$ clustered with Halorubrum species. The results of DNA-DNA hybridization and biochemical tests allowed genotypic and phenotypic differentiation of strain $5.1^{\top}$ from other Halorubrum species. The name Halorubrum ezzemoulense sp. nov. (type strain $5.1^{\top}=$ CECT $7099^{\top}=\mathrm{DSM}$ $\left.17463^{\top}\right)$ is proposed.
The extremely halophilic, aerobic archaea are classified within the family Halobacteriaceae. They are found in hypersaline environments such as the Dead Sea, salt lakes, salterns and sabkhas, but have also been isolated from lowersalinity environments where the $\mathrm{NaCl}$ concentration is sufficient to prevent their lysis (Elshahed et al., 2004). The current divisions are based on $16 \mathrm{~S}$ rRNA gene sequences and chemotaxonomic criteria, particularly polar lipid composition. To date, 20 genera of haloarchaea are recognized.

Members of the genus Halorubrum (McGenity \& Grant, 1995, 2001) are widely distributed in hypersaline environments and play important roles in the carbon and nitrogen cycles in this ecosystem. Currently, the genus Halorubrum comprises 12 species with validly published names: Halorubrum sodomense (Oren, 1983), Halorubrum lacusprofundi (Franzmann et al., 1988), Halorubrum saccharovorum (Tomlinson \& Hochstein, 1976), Halorubrum trapanicum (Petter, 1931; McGenity \& Grant, 1995), Halorubrum tebenquichense (Lizama et al., 2002), Halorubrum tibetense (Fan et al., 2004), Halorubrum terrestre (Ventosa et al., 2004), Halorubrum xinjiangense (Feng et al., 2004) and Halorubrum alkaliphilum (Feng et al., 2005). Oren \& Ventosa (1996) reclassified Halorubrobacterium coriense (Kamekura \& Dyall-Smith, 1995) and Halorubrobacterium

The GenBank/EMBL/DDBJ accession number for the $16 \mathrm{~S}$ rRNA gene sequence of strain $5.1^{\top}$ is DQ118426. distributum (Zvyagintseva \& Tarasov, 1987; Kamekura \& Dyall-Smith, 1995) as Halorubrum coriense and Halorubrum distributum, respectively. Natronobacterium vacuolatum (Mwatha \& Grant, 1993) was also reclassified as Halorubrum vacuolatum by Kamekura et al. (1997).

In this paper, a novel halophilic archaeon designated strain $5.1^{\mathrm{T}}$ belonging to the genus Halorubrum is described. Strain $5.1^{\mathrm{T}}$ was isolated from water samples collected from Ezzemoul sabkha, in north-east Algeria. Halophilic medium modified from the formulation of Oren (1983) was used, comprising (per litre distilled water): $125 \mathrm{~g} \mathrm{NaCl}, 100 \mathrm{~g}$ $\mathrm{MgCl}_{2} \cdot 6 \mathrm{H}_{2} \mathrm{O}, 5 \mathrm{~g} \mathrm{~K} \mathrm{SO}_{4}, 0 \cdot 1 \mathrm{~g} \mathrm{CaCl} \cdot 2 \mathrm{H}_{2} \mathrm{O}, 1 \mathrm{~g}$ yeast extract, $1 \mathrm{~g}$ Casamino acids and $2 \mathrm{~g}$ soluble starch. The $\mathrm{pH}$ was adjusted to $7 \cdot 0$ and incubation was at $37^{\circ} \mathrm{C}$. The following reference strains were used for comparative purposes: Hrr. sodomense DSM $3755^{\mathrm{T}}, \mathrm{Hrr}$. saccharovorum DSM $1137^{\mathrm{T}}$, Hrr. lacusprofundi DSM 5036 ${ }^{\mathrm{T}}$, Hrr. coriense DSM $10284^{\mathrm{T}}$, Hrr. tebenquichense CECT $5317^{\mathrm{T}}$, Hrr. trapanicum NRC $34021^{\mathrm{T}}$, Hrr. distributum JCM $9100^{\mathrm{T}}$, Hrr. xinjiangense JCM $12388^{\mathrm{T}}$ and Hrr. terrestre JCM $10247^{\mathrm{T}}$. The reference strains were cultured in medium $\mathrm{HE}$, at a final concentration of approximately $25 \%(\mathrm{w} / \mathrm{v})$ salts (Torreblanca et al., $1986)$ and supplemented with $0 \cdot 1 \%(\mathrm{w} / \mathrm{v})$ glucose.

Phenotypic analysis of strain $5.1^{\mathrm{T}}$ was performed according to the proposed minimal standard for the description of new taxa in the order Halobacteriales (Oren et al., 1997). Cell 
morphology was examined using transmission electron microscopy. Gram staining was performed by using aceticacid-fixed samples, as described by Dussault (1955). Growth rates in various salt concentrations were determined in medium supplemented with $0,7 \cdot 5,10,15,20,25$ or $30 \%$ $(\mathrm{w} / \mathrm{v}) \mathrm{NaCl}$ and the requirement for $\mathrm{Mg}^{2+}$ was tested using agar plates containing final concentrations of $0,0 \cdot 005,0 \cdot 01$, $0 \cdot 02,0 \cdot 1,0 \cdot 5,0 \cdot 7$ or $0 \cdot 8 \mathrm{M} \mathrm{MgCl}_{2}$. The $\mathrm{pH}$ range for growth was determined using solid medium at $\mathrm{pH} 5 \cdot 0,6 \cdot 0,6 \cdot 5,7 \cdot 0$, $7 \cdot 5,8 \cdot 0,8 \cdot 5$ and $9 \cdot 0$. Temperatures tested included $4,22,30$, $37,40,50,55$ and $60^{\circ} \mathrm{C}$. Anaerobic growth in the presence of L-arginine and nitrate was tested as described by Hartmann et al. (1980). Controls without arginine and nitrate were included and incubation was performed in the dark. Reduction of nitrate was detected by using the sulfanilic acid and $\alpha$-naphthylamine reagent (Smibert \& Krieg, 1981). Tests for formation of indole and hydrolysis of starch and aesculin were performed as described by González et al. (1978). Hydrolysis of gelatin and Tween 80 was tested as outlined by Gutiérrez \& González (1972). Catalase and oxidase activities were tested according to Gerhardt et al. (1994). Utilization of carbohydrates, sugar alcohols, amino acids and organic acids were carried out as described by Oren et al. (1997). Acid production from carbohydrates and sugar alcohols was detected using a phenol red solution. Antibiotic susceptibility was determined by spreading bacterial suspensions on culture plates and applying disks impregnated with the antibiotics tested (Bonelo et al., 1984).

Lipids were extracted from the strains using a modified Bligh and Dyer extraction procedure (Kates, 1972). The lipids were separated by thin-layer chromatography with single development on silica gel in a chloroform/methanol/acetic acid/water $(85: 22 \cdot 5: 10: 4$, by vol. $)$ solvent system. In addition, two-dimensional chromatography was performed using chloroform/methanol/water $(65: 25: 4$, by vol. $)$ in the first dimension and chloroform/methanol/acetic acid/ water $(80: 12: 15: 4$, by vol.) in the second dimension. Glycolipid spots were detected by spraying the plates with $0.5 \% \alpha$-naphthol in $50 \%$ methanol, followed by $5 \%$ sulfuric acid in ethanol and heating at $150^{\circ} \mathrm{C}$. Phospholipids were visualized with an ammonium molybdate/sulfuric acid spray.

Genomic DNA was extracted and purified by using the method of Lind \& Ursing (1986). Purity was assessed from $A_{260} / A_{280}$ and $A_{230} / A_{260}$ ratios. The $\mathrm{G}+\mathrm{C}$ content was determined from the mid-point value $\left(T_{\mathrm{m}}\right)$ of the thermal denaturation profile (Marmur \& Doty, 1962), with a Perkin Elmer UV-Vis Lambda 3B spectrophotometer at $260 \mathrm{~nm}$, programmed for temperature increases of $1.0{ }^{\circ} \mathrm{C} \mathrm{min}^{-1}$. The $T_{\mathrm{m}}$ was determined by using the graphic method described by Ferragut \& Leclerc (1976) and the G+C content was calculated from this temperature by using the equation of Owen \& Hill (1979). DNA-DNA hybridization studies were performed as described by Ziemke et al. (1998). DNA was double-labelled using DIG-11-dUTP and biotin16-dUTP (Boehringer Mannheim). The labelling reaction was carried out using a Boehringer Mannheim nicktranslation kit.

16S rRNA genes were amplified by PCR with a primer set designed to complement the highly conserved regions of the Halobacterium salinarum and Halorubrum species $16 \mathrm{~S}$ rRNA genes: forward primer F8 (5' -TTGATCCTGCCGGAGGCCATTG-3') and reverse primer R1462 (5'-ATCCAGCGCAGATTCCCCTAC-3'), corresponding to positions 8-30 and 1462-1441, respectively. PCR and sequencing were performed as described previously (Lizama et al., 2002). Multiple sequence alignments were performed using CLUSTAL W 1.8 (Thompson et al., 1994). A phylogenetic tree was constructed by using the neighbour-joining method with the MEGA 3 program package (Kumar et al., 2004).
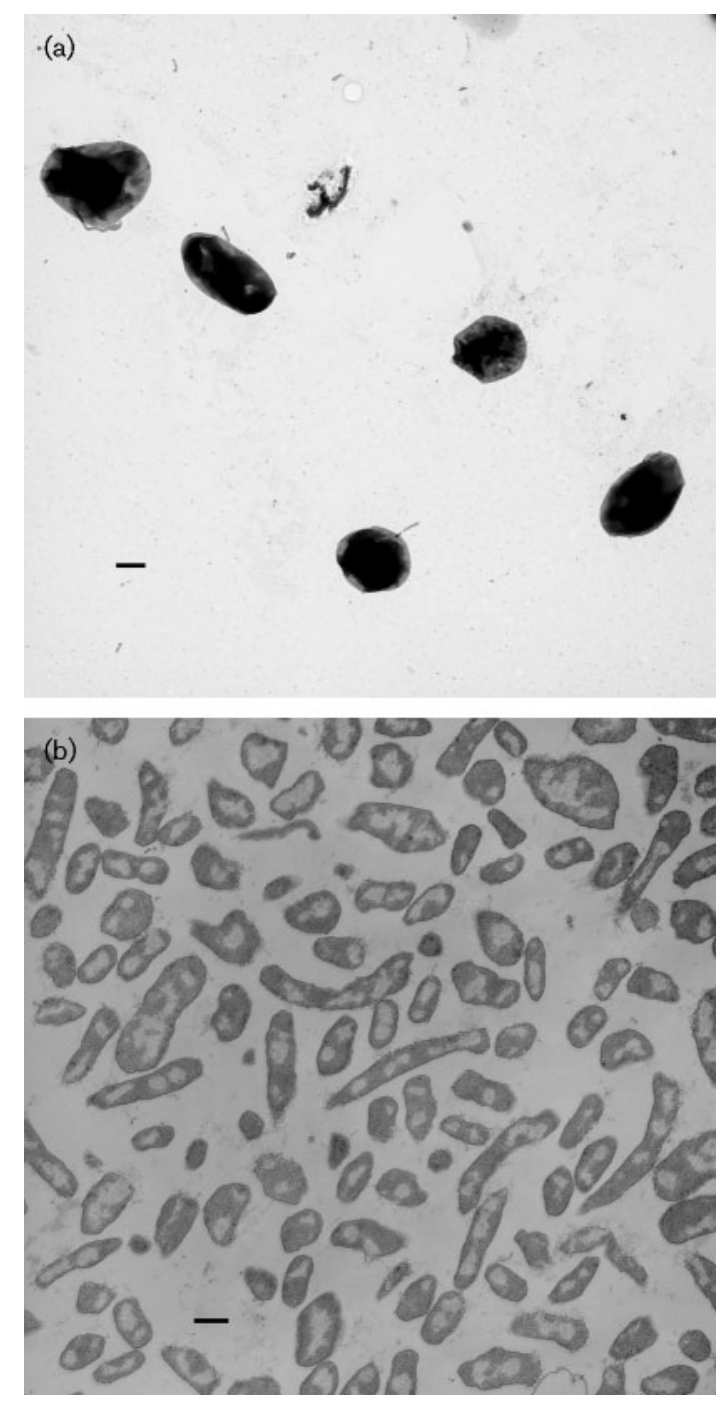

Fig. 1. Electron micrograph showing negatively stained cells (a) and transmission electron micrograph (b) of strain $5.1^{\top}$. Bars, $1 \mu \mathrm{m}$. 
On the basis of pigmentation, $\mathrm{NaCl}$-dependent growth, antibiotic susceptibility and 16S rRNA gene sequences, strain $5.1^{\mathrm{T}}$ was identified as representing a member of the family Halobacteriaceae. Colonies on standard growth agar medium were circular, convex and with entire margins. Light-red-coloured colonies, about $0.5-1.0 \mathrm{~mm}$ in diameter, were formed after 7 days of incubation at $37^{\circ} \mathrm{C}$. Cells of strain $5.1^{\mathrm{T}}$ were motile, single, small rods. Pleomorphic forms (irregular rods and coccoid and triangular forms) were also observed in liquid culture. Mean cell dimensions of the rod forms were $0.6 \times 1.5-3.0 \mu \mathrm{m}$ (Fig. 1). Cells stained Gram-negative and lysed in distilled water. Strain $5.1^{\mathrm{T}}$ grew in media containing $15-25 \%(\mathrm{w} / \mathrm{v}) \mathrm{NaCl}$, with optimum growth at $20 \%(\mathrm{w} / \mathrm{v}) \mathrm{NaCl}$. The strain grew at $\mathrm{pH} 6 \cdot 5-9 \cdot 0$, with optimum growth at $\mathrm{pH} 7 \cdot 0-7 \cdot 5$. Strain $5.1^{\mathrm{T}}$ grew at temperatures between 22 and $50{ }^{\circ} \mathrm{C} . \mathrm{Mg}^{2+}$ was required for growth and optimum growth occurred at $37-40^{\circ} \mathrm{C}$.

A number of sugars and other organic compounds stimulated growth of strain $5.1^{\mathrm{T}}$. Growth was observed with glucose, sucrose, arabinose, maltose, mannitol, glycerol, acetate, oxalate, citrate and malate. Lactose, xylose, rhamnose, galactose, raffinose, cellobiose, mannose, fructose, starch, inositol, sorbitol, dulcitol, adonitol, salicin, cellulose, malonate, fumarate, formate and amino acids were not utilized. Acid was produced in the presence of glucose, lactose, xylose, galactose and rhamnose. The isolate did not grow anaerobically with L-arginine or nitrate, but reduced nitrate to nitrite. Strain $5.1^{\mathrm{T}}$ was catalase- and oxidasepositive, but indole was not produced. The strain was resistant to penicillin, chloramphenicol, ampicillin, rifampicin, streptomycin and neomycin, but was sensitive to novobiocin and bacitracin.

Strain $5.1^{\mathrm{T}}$ contained $\mathrm{C}_{20} \mathrm{C}_{20}$ derivatives of phosphatidylglycerol and phosphatidylglycerol phosphate methyl ester, and phosphatidylglycerol sulfate and a single glycolipid, chromatographically identical to S-DGD-3 of Hrr. coriense DSM $10284^{\mathrm{T}}$.

The 16S rRNA gene sequence of strain $5.1^{\mathrm{T}}$ was determined and comparison with the 16S rRNA gene sequences of members of the family Halobacteriaceae placed strain $5.1^{\mathrm{T}}$ in the genus Halorubrum (Fig. 2). Strain $5.1^{\mathrm{T}}$ was related to Hrr. coriense ( $97 \% 16 \mathrm{~S}$ rRNA gene sequence similarity), Hrr. sodomense ( $97 \%$ similarity), Hrr. trapanicum (96\%), Hrr. distributum (96\%), Hrr. xinjiangense (96\%), Hrr. terrestre (95\%), Hrr. tebenquichense (94\%), Hrr. saccharovorum $(93 \%)$ and Hrr. lacusprofundi (93\%).

The $\mathrm{G}+\mathrm{C}$ content of the DNA of strain $5.1^{\mathrm{T}}$ was $61.9 \mathrm{~mol} \%$ $\left(T_{\mathrm{m}}\right)$ (mean of three independent determinations). DNADNA reassociation values were determined between strain $5.1^{\mathrm{T}}$ and the type strains of closely related Halorubrum species. Strain $5.1^{\mathrm{T}}$ showed relatively low DNA-DNA reassociation values with $H r r$. sodomense DSM $3755^{\mathrm{T}}$ $(32 \cdot 4 \%)$, Hrr. distributum JCM $9100^{\mathrm{T}}(21 \cdot 3 \%)$, Hrr. coriense DSM $10284^{\mathrm{T}}(18 \cdot 2 \%)$, Hrr. trapanicum NRC $34021^{\mathrm{T}}(17 \cdot 5 \%)$ and Hrr. xinjiangense JCM $12388^{\mathrm{T}}$ (16.9\%), and less than $15 \%$ with Hrr. saccharovorum DSM $1137^{\mathrm{T}}$, Hrr. lacusprofundi DSM $5036^{\mathrm{T}}$, Hrr. tebenquichense CECT $5317^{\mathrm{T}}$ and Hrr. terrestre JCM $10247^{\mathrm{T}}$. Characteristics that differentiated strain $5.1^{\mathrm{T}}$ from other Halorubrum species are listed in Table 1.

On the basis of low levels of DNA-DNA hybridization, polar lipid composition and other phenotypic differences among the novel and previously described taxa, we conclude that strain $5.1^{\mathrm{T}}$ should be considered as representing a novel species of the genus Halorubrum.

\section{Description of Halorubrum ezzemoulense sp. nov.}

Halorubrum ezzemoulense (ez.ze.mou.len'se. N.L. neut. adj. ezzemoulense pertaining to Ezzemoul sabkha, where the type strain was isolated).

Cells stain Gram-negative, are motile, lyse in distilled water and are pleomorphic. Cells occur mostly as single rods and exhibit a range of morphological types, including irregular rod-shaped, cocci and triangular forms. Rods are $0.6 \times 1 \cdot 5-$ $3.0 \mu \mathrm{m}$. Colonies on standard agar growth medium are $0.5-1.0 \mathrm{~mm}$ in diameter, circular, convex, entire and red. Chemo-organotrophic, aerobic growth occurs at 15-25\%

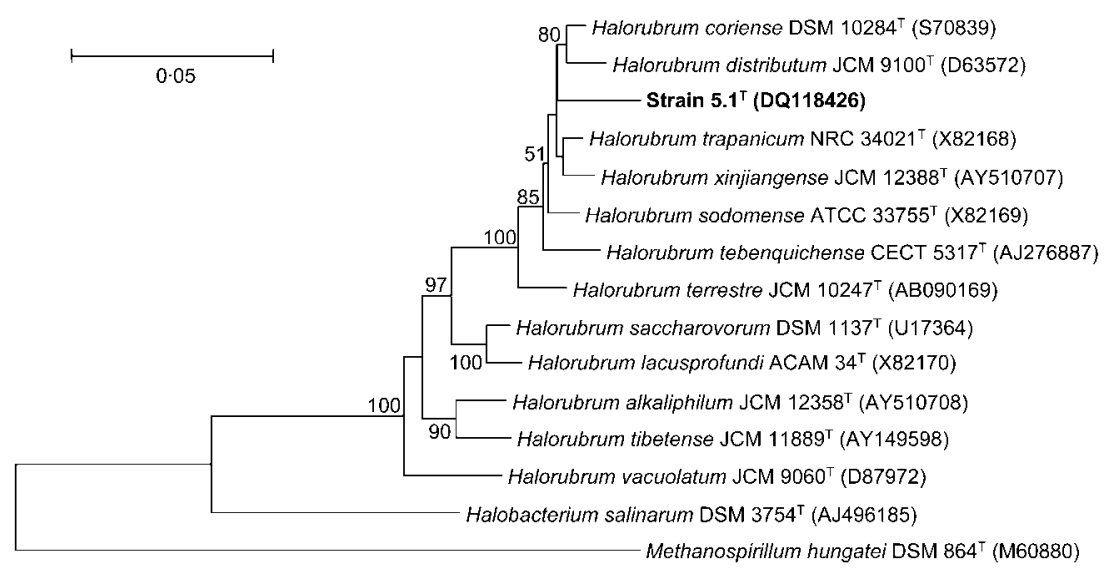

Fig. 2. Phylogenetic tree showing the position of strain $5.1^{\top}$ among species of the genus Halorubrum. The 16S rRNA gene sequence of Methanospirillum hungatei DSM $864^{\top}$ was used as an outgroup. Numbers at branch points indicate the level of bootstrap support, based on 100 resamplings. Only values greater than 50 are shown. Bar, 5 substitutions per 100 nucleotides. 
Table 1. Differential characteristics of Halorubrum ezzemoulense sp. nov. strain $5.1^{\top}$ and other Halorubrum species

Strains: 1 , strain $5.1^{\mathrm{T}} ; 2$, Hrr. coriense DSM $10284^{\mathrm{T}} ; 3$, Hrr. sodomense DSM $3755^{\mathrm{T}} ; 4, H r r$. trapanicum NRC $34021^{\mathrm{T}} ; 5$, Hrr. saccharovorum ATCC $29252^{\mathrm{T}}$; 6, Hrr. lacusprofundi JCM

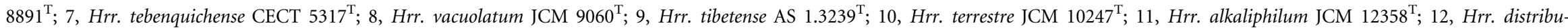
tum JCM 9100 ${ }^{\mathrm{T}}$; 13, Hrr. xinjiangense JCM $12388^{\mathrm{T}}$. Data were taken from Grant et al. (2001), Lizama et al. (2002), Ventosa et al. (2004), Fan et al. (2004), Feng et al. (2004, 2005) and this study. +, Positive; -, negative; ND, not determined.

\begin{tabular}{|c|c|c|c|c|c|c|c|c|c|c|c|c|c|}
\hline Characteristic & 1 & 2 & 3 & 4 & 5 & 6 & 7 & 8 & 9 & 10 & 11 & 12 & 13 \\
\hline Motility & + & + & + & - & + & + & ND & - & - & + & + & + & + \\
\hline Gas vacuoles & - & - & - & - & - & - & ND & + & - & - & - & - & - \\
\hline $\mathrm{NaCl}$ range for growth $(\mathrm{M})$ & $2 \cdot 5-4 \cdot 3$ & $2 \cdot 0-5 \cdot 2$ & $0 \cdot 5-4 \cdot 3$ & $2 \cdot 5-5 \cdot 2$ & $1 \cdot 5-5 \cdot 2$ & $1 \cdot 5-5 \cdot 2$ & $2 \cdot 5-5 \cdot 2$ & $2 \cdot 5-5 \cdot 2$ & $1 \cdot 7-5 \cdot 2$ & $2 \cdot 5-5 \cdot 2$ & $1 \cdot 8-5 \cdot 2$ & $1 \cdot 7-5 \cdot 2$ & $2 \cdot 0-5 \cdot 2$ \\
\hline $\mathrm{Mg}^{2+}$ requirement & + & + & + & $\mathrm{ND}$ & + & + & - & - & - & $\mathrm{ND}$ & - & ND & - \\
\hline Growth at $\mathrm{pH} 10 \cdot 5$ & - & - & - & - & - & - & - & + & + & - & + & - & - \\
\hline Temperature range for growth $\left({ }^{\circ} \mathrm{C}\right)$ & $22-50$ & $30-56$ & $20-50$ & $\mathrm{ND}$ & $30-56$ & $4-40$ & $35-50$ & $20-50$ & $22-45$ & $28-50$ & $20-44$ & $26-50$ & $10-54$ \\
\hline Hydrolysis of starch & - & $\mathrm{ND}$ & + & - & - & - & - & - & - & - & - & - & - \\
\hline \multicolumn{14}{|l|}{ Utilization of: } \\
\hline Glucose & + & + & + & + & + & + & + & + & + & - & + & - & + \\
\hline Sucrose & + & + & + & + & + & ND & ND & + & + & - & - & - & + \\
\hline Lactose & - & + & - & - & + & + & $\mathrm{ND}$ & ND & - & ND & - & ND & - \\
\hline Galactose & - & ND & - & + & + & + & + & + & - & ND & - & - & - \\
\hline Acetate & + & ND & $\mathrm{ND}$ & $\mathrm{ND}$ & $\mathrm{ND}$ & + & + & + & + & ND & - & ND & - \\
\hline Succinate & - & ND & ND & ND & ND & ND & ND & + & + & ND & - & ND & - \\
\hline Glycerol & + & + & + & + & + & - & + & ND & ND & - & + & + & - \\
\hline Acid from glucose & + & ND & + & + & + & - & - & ND & - & - & + & + & + \\
\hline $\mathrm{C}_{20} \mathrm{C}_{20}$ and $\mathrm{C}_{20} \mathrm{C}_{25}$ core lipids & - & - & - & - & - & - & ND & + & + & - & + & - & - \\
\hline Presence of PGS ${ }^{*}$ & + & + & + & + & + & + & - & - & - & + & - & + & + \\
\hline Presence of S-DGD ${ }^{*}$ & + & + & + & + & + & + & + & - & - & + & - & + & + \\
\hline $\mathrm{G}+\mathrm{C}$ content $(\mathrm{mol} \%) \dagger$ & $61 \cdot 9^{a}$ & ND & $67 \cdot 4^{b}$ & $64 \cdot 3^{b}$ & $71 \cdot 2^{b}$ & $65 \cdot 8^{b}$ & $63 \cdot 2^{a}$ & $62 \cdot 7^{a}$ & $63 \cdot 3^{a}$ & $64 \cdot 4^{a}$ & $62 \cdot 1^{a}$ & $63 \cdot 6$ & $68 \cdot 0^{b}$ \\
\hline
\end{tabular}

*PGS, Phosphatidylglycerol sulfate; S-DGD, sulfated diglycosyl diether.

$\dagger \mathrm{G}+\mathrm{C}$ content was measured by: $a, T_{\mathrm{m}}$; or $b$, buoyant density. 
(w/v) $\mathrm{NaCl}, \mathrm{pH} 6 \cdot 5-9 \cdot 0$ and $22-50^{\circ} \mathrm{C}$. Optimum $\mathrm{NaCl}$ concentration, $\mathrm{pH}$ and temperature for growth are $20 \%$ (w/v), $\mathrm{pH} 7 \cdot 0-7 \cdot 5$ and $37-40{ }^{\circ} \mathrm{C}$, respectively. $\mathrm{Mg}^{2+}$ is required for growth. Catalase- and oxidase-positive. Anaerobic growth with nitrate or L-arginine does not occur. Nitrate is reduced to nitrite. Indole is not produced. Gelatin is not liquefied. Starch, aesculin and Tween 80 are not hydrolysed. Lactose, xylose, rhamnose, galactose, raffinose, cellobiose, mannose, fructose, starch, inositol, sorbitol, dulcitol, adonitol, salicin, cellulose, malonate, fumarate, formate and amino acids are not utilized. Glucose, sucrose, maltose, arabinose, mannitol, glycerol, acetate, oxalate, citrate and malate are used as carbon sources. Acids are produced from glucose, lactose, xylose, galactose and rhamnose. Sensitive to novobiocin and bacitracin, but resistant to penicillin, chloramphenicol, ampicillin, rifampicin, streptomycin and neomycin. Polar lipids are $\mathrm{C}_{20} \mathrm{C}_{20}$ derivatives of phosphatidylglycerol and phosphatidylglycerol phosphate methyl ester. Also contains phosphatidylglycerol sulfate and a sulfated diglycosyl diether. The $\mathrm{G}+\mathrm{C}$ content of genomic DNA of the type strain is $61.9 \mathrm{~mol} \%\left(T_{\mathrm{m}}\right)$.

The type strain, $5.1^{\mathrm{T}}\left(=\right.$ CECT $7099^{\mathrm{T}}=$ DSM $\left.17463^{\mathrm{T}}\right)$, was isolated from Ezzemoul sabkha in Algeria.

\section{Acknowledgements}

This study was supported by grants from the Junta de Andalucía (project CVI 190), Spain and with support from the Algerian Ministry of Education.

\section{References}

Bonelo, G., Ventosa, A., Megias, M. \& Ruiz-Berraquero, F. (1984). The sensitivity of halobacteria to antibiotics. FEMS Microbiol Lett 21, 341-345.

Dussault, H. P. (1955). An improved technique for staining red halophilic bacteria. J Bacteriol 70, 484-485.

Elshahed, M. S., Najar, F. Z., Roe, B. A., Oren, A., Dewers, T. A. \& Krumholz, L. R. (2004). Survey of archaeal diversity reveals an abundance of halophilic Archaea in a low-salt, sulfide- and sulfurrich spring. Appl Environ Microbiol 70, 2230-2239.

Fan, H., Xue, Y., Ma, Y., Ventosa, A. \& Grant, W. D. (2004). Halorubrum tibetense sp. nov., a novel haloalkaliphilic archaeon from Lake Zabuye in Tibet, China. Int J Syst Evol Microbiol 54, 1213-1216.

Feng, J., Zhou, P.-J. \& Liu, S.-J. (2004). Halorubrum xinjiangense sp. nov., a novel halophile isolated from saline lakes in China. Int J Syst Evol Microbiol 54, 1789-1791.

Feng, J., Zhou, P., Zhou, Y.-G., Liu, S.-J. \& Warren-Rhodes, K. (2005). Halorubrum alkaliphilum sp. nov., a novel haloalkaliphile isolated from a soda lake in Xinjiang, China. Int J Syst Evol Microbiol 55, 149-152.

Ferragut, C. \& Leclerc, H. (1976). Etude comparative des méthodes de détermination du $\mathrm{T}_{\mathrm{m}}$ de l'ADN bactérien. Ann Microbiol 127A, 223-235 (in French).

Franzmann, P. D., Stackebrandt, E., Sanderson, K., Volkman, J. K., Cameron, D. E., Stevenson, P. L., McMeekin, T. A. \& Burton, H. R. (1988). Halobacterium lacusprofundi sp. nov., a halophilic bacterium isolated from Deep Lake, Antarctica. Syst Appl Microbiol 11, 20-27.
Gerhardt, P., Murray, R. G. E., Wood, W. A. \& Krieg, N. R. (editors) (1994). Methods for General and Molecular Bacteriology. Washington, DC: American Society for Microbiology.

González, C., Gutiérrez, C. \& Ramírez, C. (1978). Halobacterium vallismortis sp. nov. An amylolytic and carbohydrate-metabolizing, extremely halophilic bacterium. Can J Microbiol 24, 710-715.

Grant, W. D., Kamekura, M., McGenity, T. J. \& Ventosa, A. (2001). Order 1. Halobacteriales Grant and Larsen 1989b, 495 ${ }^{\mathrm{VP}}$ (effective publication: Grant and Larsen 1989a, 2216). In Bergey's Manual of Systematic Bacteriology, 2nd edn, vol. 1, pp. 294-334. Edited by D. R. Boone, R. W. Castenholz \& G. M. Garrity. New York: Springer.

Gutiérrez, C. \& González, C. (1972). Method for simultaneous detection of proteinase and esterase activities in extremely halophilic bacteria. Appl Microbiol 24, 516-517.

Hartmann, R., Sickinger, H.-D. \& Oesterhelt, D. (1980). Anaerobic growth of halobacteria. Proc Natl Acad Sci U S A 77, 3821-3825.

Kamekura, M. \& Dyall-Smith, M. L. (1995). Taxonomy of the family Halobacteriaceae and the description of two new genera Halorubrobacterium and Natrialba. J Gen Appl Microbiol 41, 333-350.

Kamekura, M., Dyall-Smith, M. L., Upasani, V., Ventosa, A. \& Kates, M. (1997). Diversity of alkaliphilic halobacteria: proposals for transfer of Natronobacterium vacuolatum, Natronobacterium magadii, and Natronobacterium pharaonis to Halorubrum, Natrialba, and Natronomonas gen. nov., respectively, as Halorubrum vacuolatum comb. nov., Natrialba magadii comb. nov., and Natronomonas pharaonis comb. nov., respectively. Int J Syst Bacteriol 47, 853-857.

Kates, M. (1972). Techniques of Lipidology. New York: Elsevier.

Kumar, S., Tamura, K. \& Nei, M. (2004). MEGA 3: integrated software for molecular evolutionary genetics analysis and sequence alignment. Brief Bioinform 5, 150-163.

Lind, E. \& Ursing, J. (1986). Clinical strains of Enterobacter agglomerans (synonyms: Erwinia herbicola, Erwinia milletiae) identified by DNA-DNA-hybridization. Acta Pathol Microbiol Immunol Scand [B] 94, 205-213.

Lizama, C., Monteoliva-Sánchez, M., Suárez-García, A., RossellóMora, R., Aguilera, M., Campos, V. \& Ramos-Cormenzana, A. (2002). Halorubrum tebenquichense sp. nov., a novel halophilic archaeon isolated from the Atacama Saltern, Chile. Int J Syst Evol Microbiol 52, 149-155.

Marmur, J. \& Doty, P. (1962). Determination of the base composition of deoxyribonucleic acid from its thermal denaturation temperature. J Mol Biol 5, 109-118.

McGenity, T. J. \& Grant, W. D. (1995). Transfer of Halobacterium saccharovorum, Halobacterium sodomense, Halobacterium trapanicum NRC 34021 and Halobacterium lacusprofundi to the genus Halorubrum gen. nov., as Halorubrum saccharovorum comb. nov., Halorubrum sodomense comb. nov., Halorubrum trapanicum comb. nov., and Halorubrum lacusprofundi comb. nov. Syst Appl Microbiol 18, 237-243.

McGenity, T. J. \& Grant, W. D. (2001). Genus VII. Halorubrum McGenity and Grant 1996, 362 ${ }^{\mathrm{VP}}$ (effective publication: McGenity and Grant 1995, 241). In Bergey's Manual of Systematic Bacteriology, 2nd edn, vol. 1, pp. 320-324. Edited by D. R. Boone, R. W. Castenholz \& G. M. Garrity. New York: Springer.

Mwatha, W. E. \& Grant, W. D. (1993). Natronobacterium vacuolata sp. nov., a haloalkaliphilic archaeon isolated from Lake Magadi, Kenya. Int J Syst Bacteriol 43, 401-404.

Oren, A. (1983). Halobacterium sodomense sp. nov., a Dead Sea halobacterium with an extremely high magnesium requirement. Int J Syst Bacteriol 33, 381-386.

Oren, A. \& Ventosa, A. (1996). A proposal for the transfer of Halorubrobacterium distributum and Halorubrobacterium coriense to 
the genus Halorubrum as Halorubrum distributum comb. nov. and Halorubrum coriense comb. nov., respectively. Int J Syst Bacteriol 46, 1180.

Oren, A., Ventosa, A. \& Grant, W. D. (1997). Proposed minimal standards for description of new taxa in the order Halobacteriales. Int J Syst Bacteriol 47, 233-238.

Owen, R. J. \& Hill, L. R. (1979). The estimation of base compositions, base pairing and genome size of bacterial deoxyribonucleic acids. In Identification Methods for Microbiologists, pp. 277-296. Edited by F. A. Skinner \& D. W. Lovelock. London: Academic Press.

Petter, H. F. M. (1931). On bacteria of salted fish. Proc K Ned Akad Wet 34, 1417-1423.

Smibert, R. M. \& Krieg, N. R. (1981). General characterization. In Manual of Methods for General Bacteriology, pp. 409-443. Edited by P. Gerhardt, R. G. E. Murray, R. N. Costilow, E. W. Nester, W. A. Wood, N. R. Krieg \& G. B. Phillips. Washington, DC: American Society for Microbiology.

Thompson, J. D., Higgins, D. G. \& Gibson, T. J. (1994). CLUSTAL W: improving the sensitivity of progressive multiple sequence alignment through sequence weighting, position-specific gap penalties and weight matrix choice. Nucleic Acids Res 22, 4673-4680.

Tomlinson, G. A. \& Hochstein, L. I. (1976). Halobacterium saccharovorum sp. nov., a carbohydrate-metabolizing, extremely halophilic bacterium. Can J Microbiol 22, 587-591.

Torreblanca, M., Rodríguez-Valera, F., Juez, G., Ventosa, A., Kamekura, M. \& Kates, M. (1986). Classification of non-alkaliphilic halobacteria based on numerical taxonomy and polar lipid composition, and description of Haloarcula gen. nov. and Haloferax gen. nov. Syst Appl Microbiol 8, 89-99.

Ventosa, A., Gutiérrez, M. C., Kamekura, M., Zvyagintseva, I. S. \& Oren, A. (2004). Taxonomic study of Halorubrum distributum and proposal of Halorubrum terrestre sp. nov. Int J Syst Evol Microbiol 54, 389-392.

Ziemke, F., Höfle, M. G., Lalucat, J. \& Rosselló-Mora, R. (1998). Reclassification of Shewanella putrefaciens Owen's genomic group II as Shewanella baltica sp. nov. Int J Syst Bacteriol 48, 179-186.

Zvyagintseva, I. S. \& Tarasov, A. L. (1987). Extreme halophilic bacteria from saline soils. Mikrobiologiia 56, 839-844 (in Russian). 